(thirteen years) and that he is quite unused to the stage; it being, according to the bill, his first appearance, acquitted himself in such a manner as to promise very favourably, when a little practice and increased confifidence shall enable him to develop his latent power. The scene between him and Hubert was affecting, and obtained much applause.

Our readers will already have anticipated that the Constance of Mrs. Bartley was a failure. There are some characters that appear to have belonged so exclusively to Mrs. Siddons, and were so peculiarly adapted to her astonishing powers, that we begin almost to despair of ever again seeing them adequately filled by any other performer. We would recommend Mrs Bartley to avoid them in future, and confine herself to those where tenderness and maternal affection alone, unmixed with lofty passion or great mental energy, are required. We now see and sensibly feel the loss of such a highly-gifted being as Mrs. Siddons. Her Lady Macbeth, Queen Catherine, and Constance, are left without a representative; and to use the language of a late poet,

"Are parts when she dies should be laid in her hearse."

\section{CHESS PROBLEMS.}

No. 4 .

In the first of the following situations, the game was won in a remarkably scientific manner by the gentleman who conducted the moves of the white, who is a plaver of first-rate skill. An attentive examination of this situation will be extremely instructive to the student. The next position occurred at Prague, M. Brodezky: an eminent player in that city. conducted the white, and forced the mate by a brilliant series of moves. The next position, which we present this week to our readers, is taken from an East Indian treatise, and is one of extraordinary difficulty and complication. It appears to have been suggested by Marshal Saxe's problem, which we gave in our last Number. In that problem the student has seen the ingenious manner in which the pawns on one side were compelled to file off, to afford a passage for the white pawn; but in this problem the extremely difficult condition is superadded, that the black pawns shall not be suffered to move; a condition which seems to render its execution almost impossible. As this problem has been given rather as a specimen of the difficulties which may be surmounted by combinations at Chess, than as a practical exercise for the student, we have annexed the solution.

Philo-Lancet may be assured that there are no typographical errors, and still less any errors of calculation, in any of our problems.

Danican is right.

The Lrncet is invisible ; but we shall be always ready to give any information to our Correspondents on the subject of Chess.

Problem X.

The black having played his queen's bishop's pawn, one square, attacking the queen, the white is required to win the adverse queen, and consequently the game in five moves.

Position of the Pieces. WHYTE.

King at his knighe's square. Queen at her fourth square.

Rook at the king's bishop's square. 
King's bishop at the queen's bishop's fourth square.

Knight at the adverse king's bishop's third square.

Pawns at the king's rook's. king's knight's, queen's rook's, and queen's knight's squares, at the queen's bishop's third square, and at the adverse king's third square.

\section{BLACK.}

King at his rook's square.

Queen at her squäre.

King's rook at the king's bishop's square.

Queen's rook at its square.

Bishop at the king's 'knight's third square.

King's knight at the king's second square.

Queen's knight at its square.

Pawns at the king's rook's, queen's rook's and qucen's knight's squares ; at queen's bishop's third, and queen's third squares.

\section{XI.}

White to give checkmate in six moves.

\section{Position of the Pieces.}

\section{WHITE.}

King at his knight's second square.

Queen at the king's knight's square.

Rook at the adverse king's third square, knight at the king's knight's fourth square.

Bishop at the adverse quean's fourth square.

Pawn at the adverse king's knight's fourth square.

\section{BLACK.}

King at his rook's square.

Queen at her second square.

Rook at the king's knight's second square.

Bishop at the king's knight's third square.

Pawns at the king's rook's square, and queen's bishop's third square.

\section{XII.}

White to win with the queen's bishop's pawn in eighty-one moves, without taking any of the black pawns, or suffering them to be moved.

\section{Position of the Pieces. WHITE.}

King at his bishop's square. Queen at the king's bishop's third square.

King's bishop at the queen's third square.

Queen's bishop at the king's bishop's second square.

King's knight at the king's bishop's fourth square.

Queen's knight at adverse king's bishop's fourth square.

King's rook at adverse king's bishop's third square.

Queen's rook at adverse king's bishop's second square.

Pawns at the queen's bishop's second, and queen's knight's third squares.

BLACK.

King at his rook's square.

Pawns at the queen's knight's third, queen's knight's fourth, and adverse queen's knight's fourth squares; and at the queen's third, qucen's fourth, and adverse queen's fourth squares.

\section{Solution of Problem XII.}

We shall only give the moves of the white, where the black has bat one method of playing, and when he has an option, we shall give that move of the black, which is most favourable to the defence.

1. King's knight to adverse king's third square.

2. Kinc's knight to adverse queen's bishop's second square.

3. King's knight to adverse queen's rook's square.

4. Queen's knight to adverse king's second square, checking.

5. Queen's knight to adverse queen's bishop's third square.

6. Quven's knight to adverse queen's square, 
7. Queen's rook to adverse queen's rook's second square.

8. Queen's bishop to king's square.

9. Queen's bishop to queen's second square.

10. Queen's bishop to queen's bishop's square.

11. Queen's bishop to queen's knight's second square.

12. Queen's bishop to queen's rook's square.

13. King's rook to adverse king's bishop's second square.

14. Queen's rook to adverse queen's rook's third square.

15. Queen's knight to adverse queen's knight's second square.

16. Queen to adverse king's bishop's fourth square.

17. Queen to adverse king's third square.

18. King to king's bishop's second square.

19. King to king's bishop's third square.

20. King to king's bishop's fourth square.

21. King to adverse king's bishop's fourth square.

22. Queen to adverse king's knight's third square, checking.

23. Queen to adverse king's bishop's third square, checking.

24. King's rook to adverse king's knight's second square, checking.

25. King's rook to adverse king's knight's third square, checking.

26. Queen to adverse king's bishop's second square, checking.

27. Queen to adverse king's bishop's square, checking.

28. Rook to adverse king's knight's second square, checking:

29. Queen to adverse king's bishop's third square, checking.

30. Queen to adverse king's knight's third square, ehecking.

31. Queen to adverse king's knight's fourth square, checking.

32. Queen to king's knight's fourth square, checking.

33. Queen to king's knight's third square, checking.
34. Queen to king's bishop's third square, checking:

35. King's rook to king's knight's second square, checking.

36. King's rook to king's second square, checking.

37. Queen to king's bishop's second square, checking.

38. Queen to king's rook's fourth square, checking.

39. Queen to king's rook's second square, checking.

40. King's rook to king's knight's second square, checking.

41. Queen to king's knight's third square, checking.

42. Queen to king's bishop's third syuare, checking.

Black.-King to adverse king's square.

43. Queen to king's bishop's second square, checking.

44. Queen to king's second square, checking.

45. King's rook to king's rook's second square.

46. Queen's bishop's pawn to queen's bishop's fourth square. checking.

47. Queen to queen's knight's second square, checking.

48. Queen to queen's bishop's second square, checking.

49. King's rook to king's second square, checking.

50. King's rook to king's third square, checking.

51. Queen to queen's square, checking.

52. Queen to king's second square, checking.

53. Queen to king's bishop's square, checking.

54. King's rook to king's second square hecking.

55. King's rook to king's knight's second square, checking.

Black. - King to adverse king's rook's fourth square.

56. Queen to king's bishop's fourth square, checking.

Black.-King to adverse king's rook's third square.

57. Queen to king's bishop's third square, checking. 
58. Queen to king's knight's third square, checking.

59. Queen to king's knight's fourth square, checking.

60. Queen to adverse king's knight's fourth square, checking.

61. Queen to adverse king's knight's third square, checking.

62. Queen to adverse king's bishop's third square, checking.

63. King's rook to king's rook's second square, checking.

- 64. Queen to adverse king's knight's third square, checking.

65. King's rook to adverse king's rook's square, checking.

66. King's rook to adverse king's square, checking.

67. Queen to adverse king's third square, checking.

68. Queen's bishop's pawn one square.

69. Queen to adverse queen's second square, checking.

70. Queen's bishop's pawn one square.

71. Rook to adverse king's second square.

72. Knight to adverse queen's bishop's second square, checking.

Black.-King to queen's rook's fourth square.
73. Knight to adverse king's third square.

74. Knight to adverse queen's square.

75. Rook to adverse king's bishop's second square.

76. Knight to adverse queen's knight's second square.

77. Knight to adverse queen's bishop's fourth square, checking.

Black.-King to queen's rook's square.

78. Knight to adverse king's third square.

79. Queen to adverse queen's rook's second square.

80. Queen to adverse queen's rook's third square, checking.

81. Pawn one square, giving checkmate.

NOTICE TO CORRESPONDENTS.

If our valued Correspondent X.X. will send to the Publisher he will find a parcel directed for him. We are extremely sorry that the communication this week came too late for insertion. It will positively appear in our next.

Other Correspondents next week.

\section{ERRATA.}

Through inadvertency the following Errata crept into the Review of the Transactions of the Associated Apothecaries, in our last Number.

Page 267, line 32, for then bad it is, read then it is bad.

- 268, line 21, for attainment, read attainments.

- 269 , line 15, for the classical, read classical.

- 269, line 34, for study, read, pursue the study of his profession.

- 269 , line 43 , for tony profession, read to one member of the profession.:

- 270, line 27, for respect, read respecting.

Printed and Published by J. ONWHYN, No. 4; Catherine-street, Strand; where all Communications (post paid) are to be addressed to the Editor. ...." 